\title{
Spongivory by Parrotfish in Florida Mangrove and Reef Habitats
}

\author{
Matthew Dunlap \& Joseph R. Pawlik* \\ Biological Sciences and Center for Marine Science Research, University of North \\ Carolina at Wilmington, Wilmington, North Carolina 28403-3297, USA.
}

With 3 figures and 2 tables

Key words: Parrotfish, sponge, Sparisoma, Scarus, spicules, predation, ecology.

\begin{abstract}
Although parrotfish are generally reported to be herbivorous, increasing evidence suggests that some Caribbean species feed on sponges. After observing grazing scars on the barrel sponge, Xestospongia muta, 40 sponges were videotaped on three reefs for $>0.5 \mathrm{~h}$ to determine the frequency of parrotfish bites on this species. A total of $10 \mathrm{~h}$ of video recording captured 45 bites on normally coloured $X$. muta and 527 bites on four bleached $X$. muta by the parrotfish Sparisoma aurofrenatum, Scarus croicensis and Scarus taeniopterus. The viscera (gut and liver) of 55 parrotfish collected from mangrove and reef habitats were digested in nitric acid and analysed for spicule content. The parrotfish collected in the mangroves (mostly Scarus guacamaia and Sparisoma chrysopterum) had significantly higher masses of spicules in their viscera than did parrotfish collected on the reef (Sparisoma aurofrenatum, Sparisoma viride, Sparisoma chrysopterum, Scarus vetula, Scarus coelestinus and Scarus taeniopterus). The spicules of Geodia gibberosa, a chemically undefended sponge that is common in the mangroves but rare in exposed locations on the reef, were abundant in the viscera of parrotfish collected in the mangroves. These results provide further evidence that fish predation has an important effect on the distribution and abundance of Caribbean sponges.
\end{abstract}

\section{Problem}

Benthic-feeding marine fish possess excellent mobility and a range of sophisticated sensory capabilities that permit them to detect even well-hidden prey (СНОАт, 1982; VAN BLARICOM, 1982); hence, they are thought to be major determinants of subtidal invertebrate community structure (HIxoN, 1983). Nevertheless, there have been relatively few field studies documenting the effects of fish predation on benthic invertebrates. Reviews of research on fish predation have called for better-designed field studies of the foraging behaviour of fish and documentation of the effect on invertebrate communities (HoBson, 1974; СHOAT, 1982; HoRN, 1989; JONES et al., 1991). Specifically, there has been a call for studies that establish the identity of both predator and prey, that incorporate direct field observation, and that use direct measures of the intensity of predation to determine how predation pressure alters the distribution, abundance and structure of prey populations (JONES et al.,

*Author to whom correspondence should be addressed; e-mail: pawlikj@uncwil.edu 
1991). Such in situ experiments have been carried out for fish-seaweed interactions (HORN, 1989; CHOAT, 1991; HAY, 1991), but very few have been attempted in order to quantify fish predation on marine invertebrates.

Tropical marine sponges reportedly suffer very little predation. In the Caribbean, the only recorded major sponge predators are hawksbill turtles (MEYLAN, 1988) and a few fish species (Randall \& Hartman, 1968; WulfF, 1994). Field studies examining the visceral contents of reef fish have concluded that, although a few fish species frequently feed on sponges (Hiatt \& Strasburg, 1960; Randall \& HARTMAN, 1968), overall, there is little effect of fish predation on the ecology of sponges. Indeed, the antipredatory chemical defence mechanisms of sponges have been recognized for years (BaKus, 1981; HopPe, 1988; PAwlik, 1993; PAwlik et al., 1995).

In tropical ecosystems, parrotfish are one of the most important consumers because they are abundant (BoHNSACK etal,, 1987; SCHMITT, 1996) and forage intensely (BrugGemann et al., 1994a,c). Their importance in affecting algal communities (HAY, 1991; HIXON \& BROSTOFF, 1996) and distributing carbonate sediments (BARDACH, 1961; BellwoOd, 1996) is well documented, with feeding rates for juvenile and terminal-phase fish as high as 28000 and 16000 bites per day, respectively (BRUGGEMANN etal., 1994b). While parrotfish are generally reported to be herbivorous, recent work suggests that some parrotfish species consume sponges (DunlaP \& PaWlik, 1996; WulfF, 1997).

Previously, we have videotaped vigorous feeding by parrotfish species on sponges that had been transplanted from mangrove habitats (DUNLAP \& PAWLIK, 1996). Of over 35000 fish bites recorded in the 5-day experiment, $34.8 \%$ were taken by parrotfish, mostly Sparisoma aurofrenatum (24.9\%) and Sparisoma chrysopterum (7.2\%). Furthermore, overturning slabs of coral and exposing the encrusting sponges growing on the undersides of slabs initiated feeding by the same assortment of reef fish videotaped in the experiment (DUNLAP \& PAwLIK, 1996).

At the same time as we were conducting the foregoing experiments, we noticed grazing scars that appeared to have been caused by parrotfish on many specimens of Xestospongia muta, a large barrel sponge that is very abundant on the reefs off Key Largo, Florida. The scars were visible because the interior tissue of the sponge is lighter in colour than the brownish exterior, probably because of the presence of the pigment-bearing cyanobacterial symbiont Aphanocapsa feldmanni in the sponge surface (VICENTE, 1990). ChanAs \& PAwlik (1995) reported protein $\left(17 \mathrm{mg} \cdot \mathrm{ml}^{-1}\right)$, carbohydrate $\left(3 \mathrm{mg} \cdot \mathrm{ml}^{-1}\right)$, lipid $\left(10 \mathrm{mg} \cdot \mathrm{ml}^{-1}\right)$ and energy $\left(1.6 \mathrm{~kJ} \cdot \mathrm{ml}^{-1}\right)$ content values for $X$. muta that were very similar to the mean values (20.7, 3.5, 11.4 and 2.0, respectively) for 71 species of Caribbean sponges. On average, the crude organic extracts of $X$. muta deterred feeding of the reef fish Thalassoma bifasciatum in aquarium assays, but this activity exhibited a high degree of intra-specific variability (PAwLIK etal., 1995). The capacity of crude extracts of the exterior and interior tissue of the same sponge to deter feeding was not significantly different (Chanas \& Pawlik, 1995).

The objective of the present investigation was to document sponge-feeding by parrotfish in reef and mangrove habitats. As a follow-up to the initial discovery of vigorous feeding by parrotfish on mangrove sponges transplanted to the reef and on recently exposed cryptic sponges (DUNLAP \& PAWLIK, 1996), field experiments were designed to record instances of predation by parrotfish on exposed sponges 
that grow in the same habitats as the fish. Specimens of $X$. muta on the reef were videotaped for half-hour periods to estimate the frequency of parrotfish bites on sponges and to identify the species of parrotfish making the scars. In addition, parrotfish were collected from reef and mangrove environments and analysed for the amount of sponge spicules present in their gut. This work represents a further investigation of the effects of fish foraging on the ecology of sponges by identifying sponge predators and the intensity of predation. It also provides further evidence that predation by fish is a significant factor in determining the distribution and abundance of Caribbean sponges.

\section{Material and Methods}

\section{Study area}

All field work was completed in the vicinity of the National Undersea Research Center (NURC) in Key Largo, Florida, USA $\left(25^{\prime} 10^{\prime} \mathrm{N} ; 80^{\circ} 20^{\prime} \mathrm{W}\right)$ (Fig. 1). Laboratory analyses of reef fish visceral contents was completed at UNC Wilmington, Wilmington, NC, USA.

\section{Videotaping of Xestospongia muta on the reef}

An Amphibico underwater camera housing containing a Sony V99 video camera was attached to a platform on a tripod constructed of polyvinylchloride pipes. The lengths of the tripod legs were adjustable so that the tripod could be set on irregular surfaces, and each leg was weighted with a $1 \mathrm{~kg}$ lead diving weight. The tripod was placed either directly over the sponges, or $1 \mathrm{~m}$ away, whichever viewpoint gave the best perspective for recording the fish behaviour.

Before deploying the camera at any given site, the area was surveyed to locate sponge specimens with the most grazing scars. Both heavily scarred sponges and sponges which showed no scars were videotaped. In some cases, several sponges fitted within the camera view-frame and could be videotaped simultaneously. Videotaping was conducted from 30 July to 2 August 1996. All videotaping was conducted at 12-14 m depth on three reefs: Conch Reef, Molasses Reef and Grecian Dry Rocks (Fig. 1). The video camera was allowed to run continuously for at least $30 \mathrm{~min}$ while the divers either returned to the boat or continued their dives at least $20 \mathrm{~m}$ away from the camera.

For all the $X$. muta included in video recordings, grazing scars within a $64 \mathrm{~cm}^{2}$ quadrant placed on the interior surface of the barrels of each specimen were counted at four different locations per barrel. Some specimens exhibited large ( $>200 \mathrm{~mm}$ long) oval scars, while most had numerous small $(<50 \mathrm{~mm}$ ) scars that were sometimes difficult to distinguish from the irregular, bumpy surface that typifies most $X$. muta specimens.

\section{Field collection of parrotfish}

All parrotfish were collected by spearfishing. Snorkelers speared fish in the head or upper back to keep the visceral contents intact. Reef parrotfish were collected at both deep $(15 \mathrm{~m})$ and shallow $(7 \mathrm{~m})$ sites at Conch Reef and at Pickles Reef ( $5 \mathrm{~m}$ ) (Fig. 1). Mangrove parrotfish were collected in Adam's Cut, an inland boat channel that connects Blackwater and Largo Sound, both of which are fringed by extensive mangrove habitats (Fig. 1). Adam's Cut is approximately $30 \mathrm{~m}$ wide, half a mile long and 2 $8 \mathrm{~m}$ deep. Strong tidal currents are usually present in the cut, which support a heavy growth of sponges below the low tide line (approximately $80 \%$ cover). The same sponge species as those found on the walls of Adam's Cut are also present on mangrove prop roots in other locations in Blackwater and Largo Sounds. 


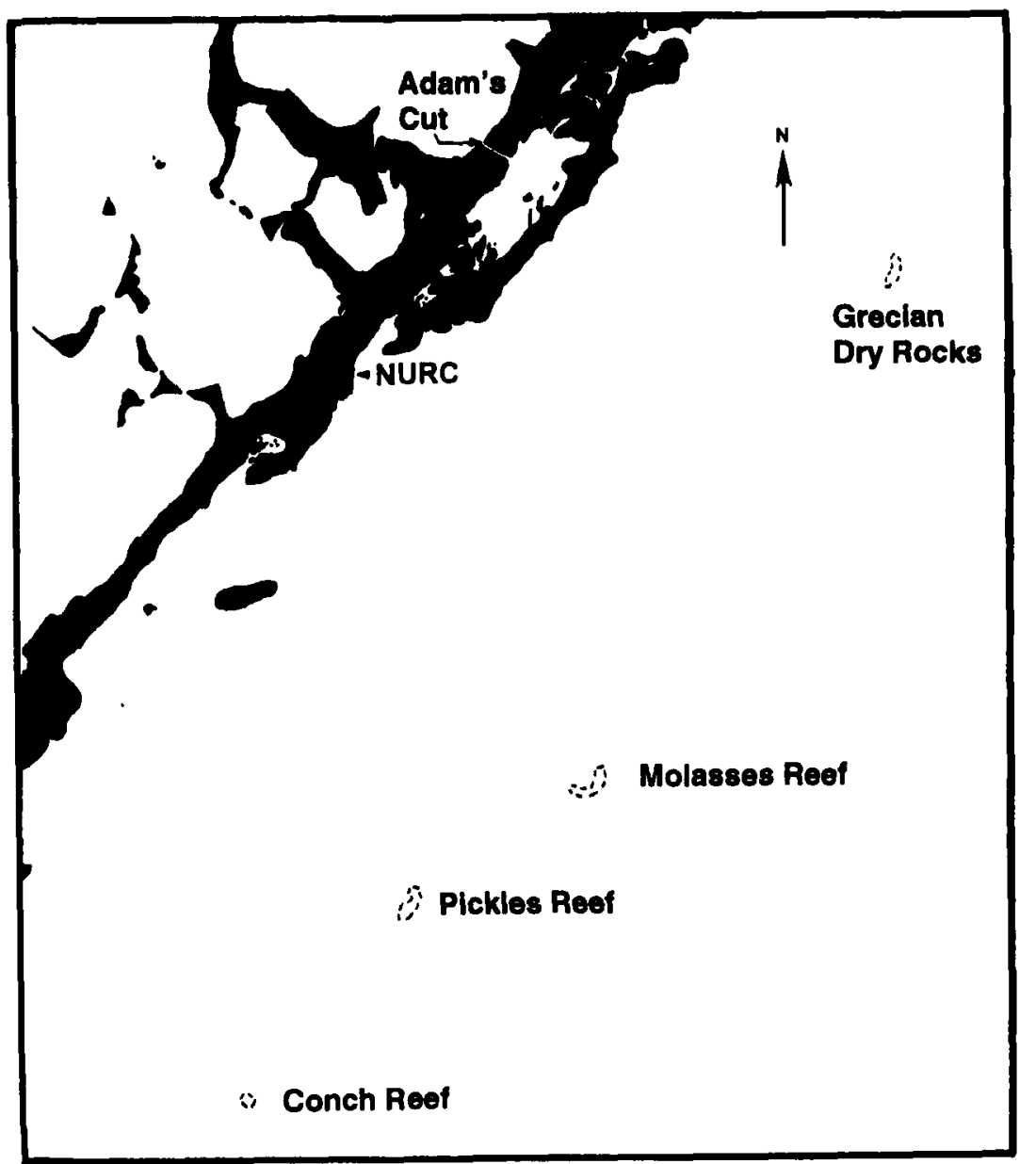

Fig. 1. Map of the northern Florida Keys in the vicinity of Key Largo showing the relationship between Adam's Cut and the offshore reefs. Latitude and longitude of Conch Reef are $24^{\prime} 57^{\prime} 00^{\prime \prime} \mathrm{N}, 80^{\prime} 27^{\prime} 27^{\prime \prime} \mathrm{W}$.

After collection, the parrotfish were transported back to the laboratory facilities at the Key Largo NURC, where standard length, blotted wet weight, species identification and phase were recorded. The entire contents of the visceral cavity were removed after making an incision from the area between the gills, along the upper edge of the gut cavity, to the anus. The visceral mass was placed in labelled plastic bags and frozen for transport back to the laboratory.

\section{Analyses of parrotfish visceral contents}

Frozen viscera were allowed to thaw, patted dry with paper towels and weighed to the nearest $0.1 \mathrm{~g}$. The displacement volume of some viscera was measured by submerging them in a graduated cylinder of distilled water. The viscera were then placed in glass beakers and oxidized with concentrated nitric acid under a laboratory hood. Oxidation of viscera with nitric acid yielded a residue of siliceous sponge spicules. Previous investigations have demonstrated that sponge spicules are unaffected by treatment with strong acid (RUTZLER \& MACINTYRE, 1978). Nitric acid was added until the sample no longer 
bubbled. The volume of acid varied from 30 to $350 \mathrm{ml}$, depending on the size of the visceral mass and the amount of carbonate present in the sample. For some visceral digestions, the liver was weighed separately and discarded without being digested. For those fish, the mass of the liver was added to gut mass for the total mass of the viscera used in the analysis. Acid digestion of the viscera required at least $24 \mathrm{~h}$, and up to $72 \mathrm{~h}$.

The spicules were washed and concentrated by sedimentation. Distilled water was repeatedly added to the beaker, stirred vigorously, allowed to sit briefly (from 10 to $30 \mathrm{~s}$ ), then poured off slowly. The beaker was tilted gradually so that the acid-water mixture, waxy material on the surface and light undigested material was poured off, but siliceous spicules remained at the bottom. Forceps or a pipette were used to remove any remaining nonsiliceous material. The remaining spicules were filtered onto a preweighed $0.8 \mu \mathrm{m}$ nylon filter and rinsed with distilled water. The filter and spicules were then dried and weighed. The spicules were examined under a dissecting microscope to confirm that the recorded mass was due to the presence of spicules rather than other material. Samples of spicules were prepared for scanning electron microscopy (SEM) using standard techniques.

Because the data were neither normal or homoscedastic, the spicule masses from mangrove and reef fish were compared using a MANN-WHITNEY nonparametric test. The means of the ratios of spicule mass divided by fish mass for mangrove and reef fish were also compared using a MANN-WHITNEY nonparametric test.

\section{Results}

\section{Video recordings of predation on Xestospongia muta}

A total of 202 min of videotaping of normally coloured $X$. muta on the reef recorded 45 parrotfish bites, while $97 \mathrm{~min}$ of videotaping of four bleached specimens of $X$. muta recorded 527 parrotfish bites. Rather than the brown appearance of most $X$. $m u t a$, the bleached sponges were either entirely white or had large patches of white tissue. The most frequent predators on the four bleached sponges videotaped at Conch Reef were schools of 10-20 juvenile Scarus croicensis or Scarus taeniopterus (juveniles could not be distinguished in the video), which took 347 bites in $28 \mathrm{~min}$, 38 bites in $28 \mathrm{~min}, 0$ bites in $30 \mathrm{~min}$ and 15 bites in $39 \mathrm{~min}$ (Table 1). On these same four sponges, and in the same amount of time, specimens of $S p$.aurofrenatum took $82,25,8$ and 12 bites, respectively (Table 1 ). Two of these sponges had very eroded surfaces and appeared to have lost significant amounts of sponge tissue. The standard lengths of the fish were not measured, but parrotfish that were feeding on sponges were estimated to be between 100 and $300 \mathrm{~mm}$ long. Grazing scars were difficult to identify and count on these sponges because of the discoloration and erosion of the surface tissue.

Of the 17 normally coloured specimens videotaped at Conch Reef, 15 were bitten by reef fish during the taping period (Table 1). At Molasses Reef, two out of nine normally coloured specimens were bitten by reef fish during the taping period. At Grecian Dry Rocks, 97 min of videotaping of normally coloured sponges captured three fish bites. Bluehead wrasse, Thalassoma bifasciatum, were occasionally observed biting at the sponges during videotaped episodes at all three sites, but the bites were not counted because it was apparent that sponge tissue was not being removed. 
Table 1. Data summary of video of fish predation on $X$. muta at three reefs off Key Largo, Florida. Circumference (c) and height (h) of sponges expressed in cm. Scars $\cdot\left(64 \mathrm{~cm}^{2}\right)^{-1}$ represents the mean of four counts of bite scars within an $8 \times 8 \mathrm{~cm}$ quadrant placed on the surface of the barrel of the sponge ( \pm SD). Total scars $\cdot\left(64 \mathrm{~cm}^{2}\right)^{-1}$ represents the mean scar tally for all scar counts made at that reef. Sa. Sc and Cs represent Sparisoma aurofrenatum, Scarus taeniopterus or Scarus croicensis, and Chaetodon sedentarius, respectively.

\begin{tabular}{|c|c|c|c|c|c|c|c|c|}
\hline \multirow[b]{2}{*}{ site } & \multirow[b]{2}{*}{ description } & \multirow[b]{2}{*}{ c } & \multirow[b]{2}{*}{ h } & \multirow{2}{*}{$\begin{array}{c}\text { scars } \\
\left(64 \mathrm{~cm}^{2}\right)^{-1}\end{array}$} & \multicolumn{4}{|c|}{ bites $\cdot(10 \mathrm{~min})^{-1}$} \\
\hline & & & & & Sa & Sc & Cs & time \\
\hline \multicolumn{9}{|c|}{ Conch Reef $(n=21)$} \\
\hline 1 & 10 normal & - & - & - & 2.5 & 0 & 4.7 & 31.6 \\
\hline 2 & 1 bleached & 65 & 64 & $10.7 \pm 2.2$ & 29.3 & 123.4 & 0 & 28 \\
\hline 2 & 1 bleached & 74 & 61 & $10.2 \pm 3.9$ & 8.9 & 13.6 & 0 & 28 \\
\hline 3 & 1 normal & - & - & $7.2 \pm 1.5$ & 3.5 & 0 & 0 & 40 \\
\hline 4 & I mostly bleached & 73 & 45 & $6.2 \pm 1.7$ & 2.7 & 0 & 0 & 29.9 \\
\hline 5 & $\begin{array}{l}\text { I normal, } \\
3 \text { barrels }\end{array}$ & $>210$ & 30 & - & 3.4 & 0.3 & 0 & 29.4 \\
\hline 6 & 1 mostly bleached & 72 & 82 & - & 3.1 & 3.8 & 0 & 39 \\
\hline 7 & I normal & 146 & 40 & $7.0 \pm 0.8$ & 0 & 0.3 & 0 & 29.5 \\
\hline 7 & 1 normal & 165 & 40 & $6.7 \pm 1.2$ & 0 & 0 & 0 & 29.5 \\
\hline 8 & I normal & 122 & 65 & $6.2 \pm 1.0$ & 0 & 0 & 3.2 & 40.6 \\
\hline 8 & I normal & 66 & 48 & $1.2 \pm 1.0$ & 0.2 & 0 & 0.7 & 40.6 \\
\hline 9 & $\begin{array}{l}\text { I normal } \\
\text { totals }\end{array}$ & 150 & 85 & $\begin{array}{l}7.8 \pm 3.3 \\
7.1 \pm 3.2\end{array}$ & 0 & 0 & 0 & $\begin{array}{r}31.4 \\
299.4\end{array}$ \\
\hline \multicolumn{9}{|c|}{ Molasses Reef ( $n=9$ ) } \\
\hline 1 & $\begin{array}{l}\text { normal, many } \\
\text { barrels }\end{array}$ & - & - & $1 \pm 1.4$ & 0 & 0 & 0 & 73.1 \\
\hline 2 & I normal & 92 & 34 & $7.5 \pm 1.9$ & 2.7 & 0 & 1.7 & 30.1 \\
\hline 3 & $\begin{array}{l}1 \text { normal, } \\
2 \text { barrels }\end{array}$ & 112 & - & $4.0 \pm 2.2$ & 0 & 0 & 0 & 27.1 \\
\hline 4 & I normal & - & - & $0 \pm 0$ & 0 & 0 & 0 & 34.7 \\
\hline 4 & $\begin{array}{l}1 \text { normal, } \\
4 \text { barrels }\end{array}$ & - & - & $5.5 \pm 1.3$ & 0 & 0 & 0 & 34.7 \\
\hline 5 & 1 normal & 35 & 54 & $1.5 \pm 1.9$ & 0.3 & 0 & 0 & 37 \\
\hline 5 & 1 normal & 71 & 55 & $6.0 \pm 1.4$ & 0 & 0 & 0 & 37 \\
\hline 5 & I normal & 85 & 57 & $7.8 \pm 1.7$ & 0 & 0 & 0 & 37 \\
\hline 5 & $\begin{array}{l}\text { I normal } \\
\text { totals }\end{array}$ & 45 & 42 & $\begin{array}{c}0 \pm 0 \\
3.7 \pm 3.3\end{array}$ & 0 & 0 & 0 & $\begin{array}{c}37 \\
202.2\end{array}$ \\
\hline \multicolumn{9}{|c|}{ Grecian Dry Rocks $(\mathrm{n}=10)$} \\
\hline 1 & 1 normal & 61 & 60 & $0 \pm 0$ & 0 & 0 & 0 & 30.7 \\
\hline 1 & 1 normal & 37 & 60 & $0 \pm 0$ & 0 & 0 & 0 & 30.7 \\
\hline 1 & 1 normal & 59 & 60 & $0 \pm 0$ & 0 & 0 & 0 & 30.7 \\
\hline 1 & 1 normal & 40 & 60 & $0 \pm 0$ & 0 & 0 & 0 & 30.7 \\
\hline 1 & 1 normal & 38 & 60 & $0 \pm 0$ & 0 & 0 & 0 & 30.7 \\
\hline 2 & 1 normal & 112 & 40 & $15.2 \pm 3.3$ & 0 & 0 & 0.6 & 34.4 \\
\hline 2 & 1 normal & 127 & 35 & $22.2 \pm 5.6$ & 0 & 0 & 0 & 34.4 \\
\hline 3 & I normal & 145 & 54 & $7.0 \pm 4.3$ & 0.3 & 0 & 0 & 31.9 \\
\hline 3 & I normal & 64 & 33 & $14.5 \pm 2.1$ & 0 & 0 & 0 & 31.9 \\
\hline 3 & $\begin{array}{l}1 \text { normal } \\
\text { totals }\end{array}$ & 56 & 35 & $\begin{array}{c}0 \pm 0 \\
5.9 \pm 8.4\end{array}$ & 0 & 0 & 0 & $\begin{array}{l}31.9 \\
97\end{array}$ \\
\hline
\end{tabular}

Total time $[\mathrm{min}]$ is the amount of time spent videotaping at each reef, excluding times when more than one sponge was being taped. $-=$ no data. 


\section{Analyses of parrotfish visceral contents}

Parrotfish collected in Adam's Cut contained significantly greater masses of spicules in their viscera than did parrotfish collected on the reef (Fig. 2). Parrotfish from

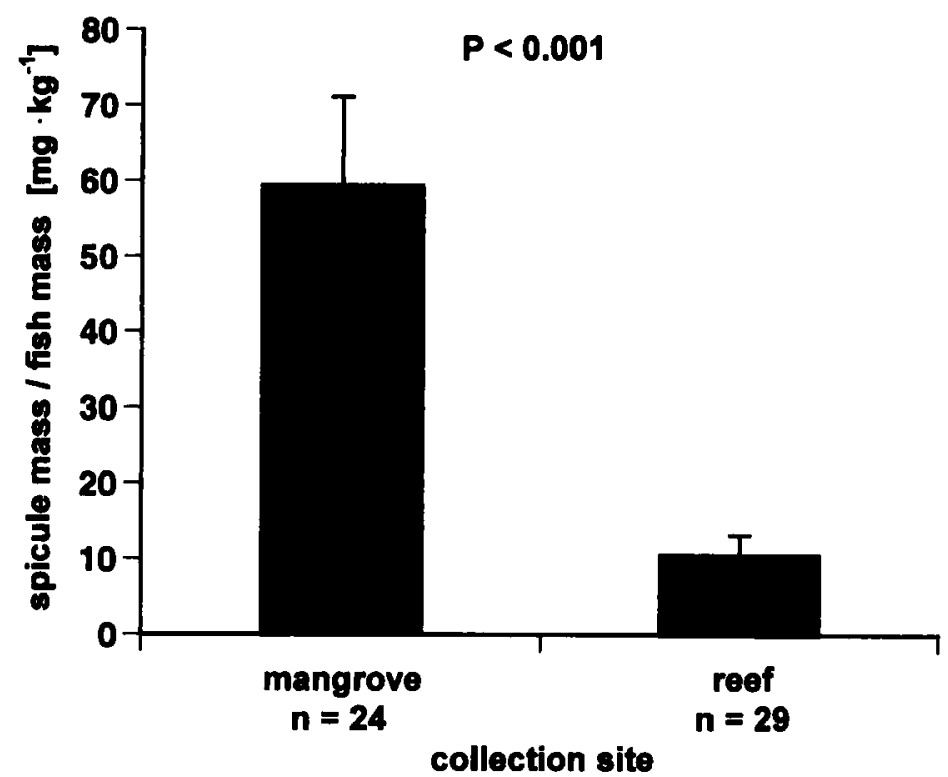

Fig. 2. Mean values ( $+\mathrm{SE}$ ) of the ratio of spicule mass from viscera divided by whole fish mass for parrotfish collected from mangrove and reef environments. There was a significant difference between the mean values for fish from the two sites (MANN-WHITNEY test).

the former site included Sparisoma chrysopterum (up to $270 \mathrm{~mm}$ standard length) and Scarus guacamaia (225-370 mm standard length) (Table 2). Scarus guacamaia were seen in schools of 10-30 individuals. The largest mass of spicules from these fish was $148 \mathrm{mg}$ from a $S c$. guacamaia that was $370 \mathrm{~mm}$ long (Table 2). Three $S c$. guacamaia had greater than $100 \mathrm{mg}$ of spicules in their viscera, and an individual that was $260 \mathrm{~mm}$ in length contained $97 \mathrm{mg}$ of spicules.

The highest spicule mass for a fish captured on the reef was $15 \mathrm{mg}$ in a specimen of $S p$. chrysopterum from Pickles Reef. The only other reef fish with a spicule mass higher than $10 \mathrm{mg}$ was a specimen of $S p$. chrysopterum collected at Conch Reef. Of 28 fish analysed, $22(79 \%)$ showed less than $5 \mathrm{mg}$ of spicules in their viscera, and spicules were absent in six of these.

To standardize for the size of the fish, spicule mass was divided by fish mass and the resulting ratio was compared between mangrove and reef fish (Fig. 2). A MANN-WHITNEY nonparametric test revealed significant differences between the mean ratios for mangrove and reef fish $(P<0.001)$. An alternative ratio (spicule mass divided by visceral mass) was calculated for fish collected in mangrove and reef habitats, and the difference between these means was also significant (data not shown). 
Table 2. Data summary of fish collections from reef and mangrove habitats. $S p$. and $S c$. represent Sparisoma and Scarus, respectively.

\begin{tabular}{|c|c|c|c|c|c|c|c|c|}
\hline species & date & site & $\begin{array}{c}\mathrm{SL} \\
{[\mathrm{mm}]}\end{array}$ & $\begin{array}{c}\text { fish wt } \\
{[\mathrm{g}]}\end{array}$ & $\begin{array}{c}\text { gut wt } \\
{[\mathrm{g}]}\end{array}$ & $\begin{array}{c}\text { liver } \\
w t \\
{[\mathrm{~g}]}\end{array}$ & $\begin{array}{l}\text { gut } \\
\text { vol } \\
\text { [ml] }\end{array}$ & $\begin{array}{c}\text { spicule } \\
\text { wt } \\
{[\mathrm{mg}]}\end{array}$ \\
\hline \multicolumn{9}{|l|}{ reef fish } \\
\hline Sp. chrysoplerum & $1 \mathrm{Mar}$ & Conch R. & 215 & 344 & - & - & - & 12 \\
\hline Sp. viride & 28 Feb & Pickles R. & 290 & 921 & 136.2 & - & - & 2 \\
\hline Sp. aurofrenatum & $28 \mathrm{Feb}$ & Pickles R & 117 & 59 & 7.8 & - & - & 0 \\
\hline Sp. aurofrenatum & $28 \mathrm{Feb}$ & Pickles R & 155 & 138 & 16.5 & - & - & 1 \\
\hline Sp. aurofrenatum & $28 \mathrm{Feb}$ & Pickles R & 145 & 105 & 14.8 & - & - & 0 \\
\hline Sp. aurofrenatum & 28 Feb & Pickles R & 160 & 175 & 21.7 & - & - & 0 \\
\hline Sp. aurofrenalum & $28 \mathrm{Feb}$ & Conch R. & 130 & 96 & 10.9 & - & - & 0 \\
\hline Sp. chrysopterum & 28 Feb & Pickles R. & 275 & 782 & 188 & - & - & 15 \\
\hline Sc. vetula & $28 \mathrm{Feb}$ & Pickles R & 225 & 385 & 46 & - & - & 3 \\
\hline Sp. chrysopterum & $28 \mathrm{Feb}$ & Pickles R & 252 & 505 & 81 & - & - & 6 \\
\hline Sp. viride & $28 \mathrm{Feb}$ & Pickles R & 290 & 704 & 127 & - & - & 8 \\
\hline Sp. chrysopterum & $28 \mathrm{Feb}$ & Pickles R & 270 & 705 & 108 & - & - & 1 \\
\hline Sp. chrysopterum & $28 \mathrm{Feb}$ & Pickles R & 237 & 483 & 78 & - & - & 5 \\
\hline Sp. aurofrenatum & 28 Feb & Conch R. & 185 & 248 & 36.7 & - & - & 2 \\
\hline Sp.chrysopterum & I Mar & Conch R. & 215 & 344 & - & - & - & 12 \\
\hline Sp. aurofrenatum & 29 Sep & Conch R. & 100 & 133 & 14.2 & 7.8 & - & 7 \\
\hline Sp. aurofrenatum & 29 Sep & Conch R. & 170 & 164 & 30 & 3.3 & 23 & 6 \\
\hline Sp. aurofienatum & $29 \mathrm{Sep}$ & Conch R. & 155 & 127 & 18 & 7.1 & 12 & 5 \\
\hline Sp. chrysopterum & $3 \mathrm{Oct}$ & Pickles R. & 285 & 949 & 116.9 & 68.5 & - & 3 \\
\hline Sp. chrysopterum & $3 \mathrm{Oct}$ & Pickles R & 255 & 536 & 42.9 & 22.5 & & 0 \\
\hline Sp. chrysopterum & $3 \mathrm{Oct}$ & Pickles R & 205 & 389 & 32.7 & 11 & - & 1 \\
\hline Sp. chrysopterum & 3 Oct & Pickles R & 210 & 336 & 36 & 4.9 & - & 0 \\
\hline Sp. viride & $3 \mathrm{Oct}$ & Pickles R & 280 & 827 & 96.3 & 26.8 & - & 2 \\
\hline Sp. viride & $3 \mathrm{Oct}$ & Pickles R & 275 & 632 & 29.7 & 21.6 & & 5 \\
\hline Sc, coelestinus & $3 \mathrm{Oct}$ & Pickles $\mathbf{R}$ & 355 & 1394 & 69.7 & 83.8 & - & 1 \\
\hline Sp. viride & 3 Oct & Pickles R & 300 & 869 & 105.9 & 42.6 & 74 & 4 \\
\hline Sc. taeniopterus & $3 \mathrm{Oct}$ & Pickles R & 290 & 920 & 49.7 & 66 & 38 & 2 \\
\hline Sc. taeniopterus & $3 \mathrm{Oct}$ & Pickles R & 295 & 957 & 67.8 & 27.8 & 61 & 2 \\
\hline Sc. taeniopterus & $3 \mathrm{Oct}$ & Pickles R & 280 & 899 & 53.2 & 73.2 & 45 & 2 \\
\hline \multicolumn{9}{|l|}{ mangrove fish } \\
\hline Sp. chrysopterum & 5 May & Adam`s Cut & 270 & - & 10.9 & - &.- & 5 \\
\hline Sc. taeniopterus & 5 May & Adam's Cut & 170 & - & 3.8 & - & & 5 \\
\hline Sc. guacamaia & $29 \mathrm{Jul}$ & Adam`s Cut & 370 & 1724 & 74.4 & & - & 40 \\
\hline Sc. guacamaia & $29 \mathrm{Jul}$ & Adam's Cut & 370 & 1406 & 151.5 & - & -- & 148 \\
\hline Sc. guacamaia & $29 \mathrm{Jul}$ & Adam's Cut & 350 & 1587 & 169 & - & -- & 121 \\
\hline Sc. guacamaia & $29 \mathrm{Jul}$ & Adam's Cut & 340 & 1496 & 173 & - & - & 42 \\
\hline Sc. guacamaia & $29 \mathrm{Jul}$ & Adam's Cut & 290 & 1088 & 106 & - & - & 45 \\
\hline Sc. guacumaia & $29 \mathrm{Jul}$ & Adam`s Cut & 310 & 1043 & 72 & - & - & 103 \\
\hline Sc. guacumaia & $29 \mathrm{Jul}$ & Adam`s Cut & 240 & 453 & 23.4 & - & - & 6 \\
\hline Sc. guacamaia & $29 \mathrm{Jul}$ & Adam's Cut & 260 & 589 & 68.2 & - & & 97 \\
\hline Sc. guacamaia & $29 \mathrm{Jul}$ & Adam's Cut & 340 & 1270 & 133.5 & - & - & 72 \\
\hline Sp. chrysopterum & $29 \mathrm{Jul}$ & Adam`s Cut & 230 & 226 & 30.9 & - & - & 5 \\
\hline Sp. chrysopterum & $29 \mathrm{Jul}$ & Adam's Cut & 240 & 272 & 25.7 & - & $\cdots$ & 9 \\
\hline Sp. chrysopterum & $29 \mathrm{Jul}$ & Adam's Cut & 245 & 317 & - & - & - & 62 \\
\hline Sp. chrysopterum & $29 \mathrm{Jul}$ & Adam's Cut & 260 & 498 & 43.9 & - & & 8 \\
\hline Sp. chrysopterum & $29 \mathrm{Jul}$ & Adam's Cut & 225 & 272 & 32.8 & 8.4 & - & 6 \\
\hline Sp.chrysopterum & $29 \mathrm{Jul}$ & Adam's Cut & 200 & 362 & 62.4 & 52.3 & - & 73 \\
\hline Sp.chrysopterum & $29 \mathrm{Jul}$ & Adam's Cut & 195 & 226 & 10.5 & - & - & 3 \\
\hline Sp.chrysopterum & $29 \mathrm{Jul}$ & Adam's Cut & 210 & 362 & 25.6 & 15.7 & - & 7 \\
\hline Sp. chrysopterum & $29 \mathrm{Jul}$ & Adam's Cut & 180 & 272 & 7.2 & - & - & 8 \\
\hline Sp. chrysopterum & $29 \mathrm{Jul}$ & Adam`s Cut & 235 & 567 & 31.5 & - & - & 6 \\
\hline Sp. chrysopterum & $29 \mathrm{Jul}$ & Adam's Cut & 180 & 227 & 8.7 & - & -- & 9 \\
\hline Sc. guacamaia & 30 Sep & Adam's Cut & 225 & 416 & 16.1 & 12.4 & 15 & 10 \\
\hline Sp. chrysopterum & 30 Sep & Adam's Cut & 220 & 330 & 16.5 & 28 & $\cdot \cdot$ & 34 \\
\hline Sp. chrysopterum & 30 Sep & Adam's Cut & 260 & 531 & 32.3 & 19.7 & 25 & 18 \\
\hline Sp. chrysopterum & 30 Sep & Adam`s Cut & 235 & 475 & 36.1 & 25.5 & 26 & 26 \\
\hline
\end{tabular}


When viewed by SEM, some of the spicules from fish viscera were fragmented, but many were still intact (Fig. 3). A spicule type that is characteristic of Geodia gibberosa was plentiful in many of the visceral samples from parrotfish collected in the mangrove habitat (Fig. 3A). Geodia gibberosa is very abundant in mangrove habitats, and samples of this sponge were rapidly consumed by parrotfish when transplanted to reef environments (DUNLAP \& PAWLIK, 1996). Portions of G. gibberosa that were collected from Adam's Cut were subjected to the same acid digestion process as fish viscera, and the spicules photographed using SEM (Fig. $3 B, D)$.
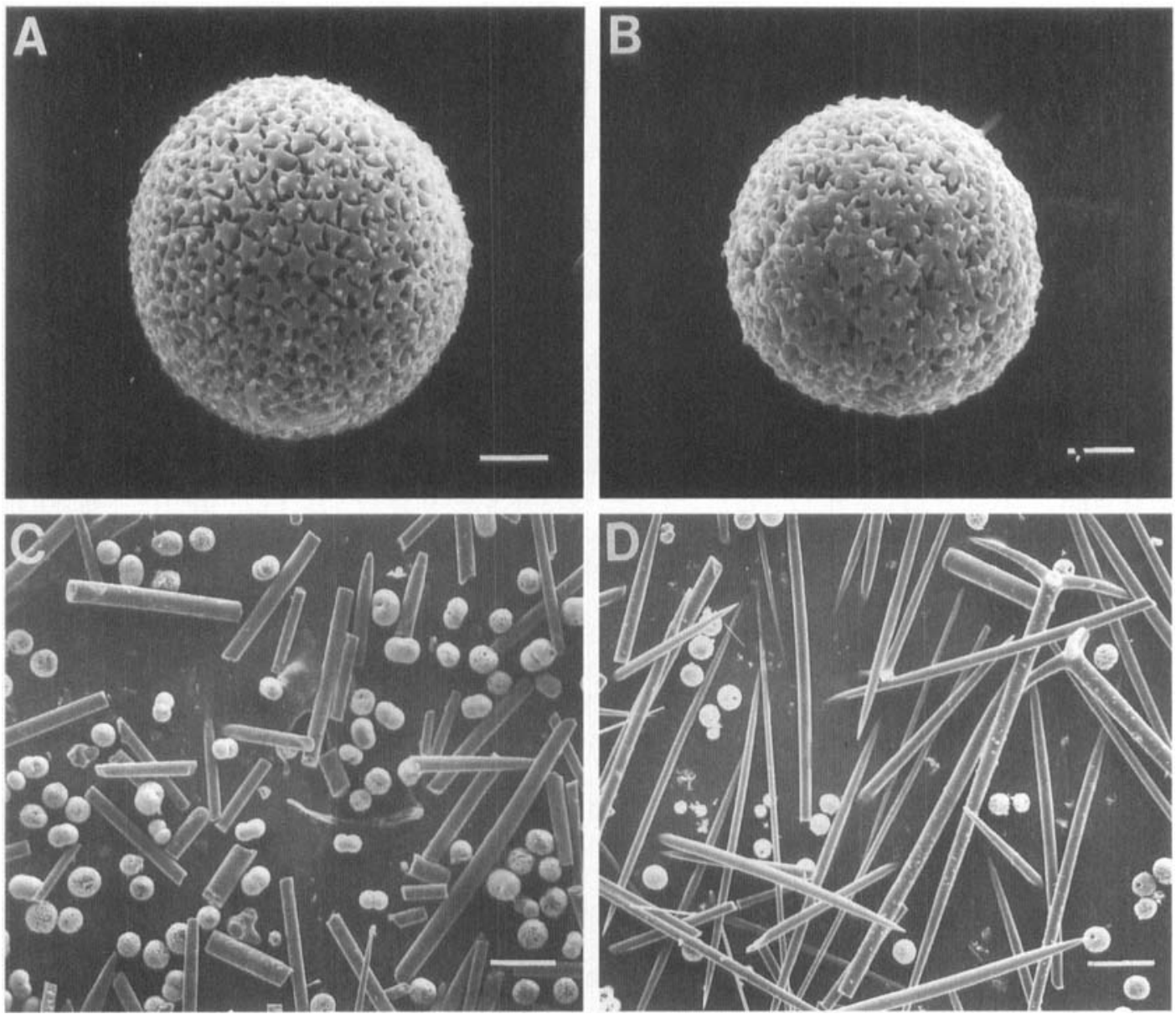

Fig. 3. Scanning electron micrographs of sponge spicules. (A) A sterraster from the gut of a parrotfish collected in Adam's Cut. (B) A sterraster from the sponge $G$. gibberosa collected in Adam's Cut. (C) Spicule residue after digesting the gut of a parrotfish collected in Adam's Cut. (D) Spicule residue after digesting a sample of G. gibberosa from Adam's Cut. Scale bars: (A, B) $10 \mu \mathrm{m}$; (C, D) $130 \mu \mathrm{m}$. 


\section{Discussion}

This study provides further evidence that parrotfish eat sponges (DUNLAP \& PAWLIK, 1996; WULFF, 1997). The frequency of bites on $X$. muta on the reef, and the amount and type of spicules found in the viscera of parrotfish collected in Adam's Cut, indicate that parrotfish predation on sponges goes beyond incidental ingestion of sponge tissue while parrotfish are feeding on algae. These findings, in combination with field observations of feeding on newly exposed cryptic sponges (DUNLAP \& PAWLIK, 1996), and transplantation experiments of mangrove sponges (PAWLIK, $1997,1998)$ indicate that fish predation has a significant impact on the distribution and abundance of some sponge species.

Grazing scars were present on the surfaces of most $X$. muta on the reefs off Key Largo, Florida. The video recordings of fish feeding on normally coloured $X$. muta documented that the grazing scars stem from bites by $S p$. aurofrenatum and other parrotfish. Particularly heavy feeding on bleached specimens of $X$. muta suggests that the presence of autotrophic symbionts is not a prerequisite for parrotfish feeding on sponges; on the contrary, it appears that feeding was enhanced in the absence of the cyanobacteria usually associated with the sponge tissue. It is not clear what caused the sponge bleaching at Conch Reef, but the same condition has been reported on a reef in Puerto Rico, where $10-30 \%$ of $X$. muta at depths of 4 $15 \mathrm{~m}$ appeared white or pale (VICENTE, 1990). The intensity of parrotfish feeding on bleached $X$. muta may indicate reduced levels of defensive chemistry in the tissues of these specimens. It is possible that the production of the chemical defence of $X$. muta is partially or wholly dependent on the presence of the cyanobacterial symbionts.

Visceral content analyses of parrotfish have reported items other than algae in the viscera. Hobson (1974) reported that parrotfish speared off Kona, Hawaii, contained bits of algae mixed with calcareous powder, organic slurry and sand. Although algae constituted less than $20 \%$ of the total visceral contents, he classified all parrotfish species in Kona as herbivores but commented that the large visceral loads of calcareous powder, organic slurry and sand seem too great a proportion of the total contents to have been taken only incidentally, or to be merely adaptive because this material aids in grinding up plant tissue, as suggested by BARDACH (1961) and RANDALL (1967). Bruggemann et al. (1994b) reported that the diet of adult Sparisoma viride on reefs in Bonaire, Netherlands Antilles, consisted almost exclusively of algae associated with dead coral substrates, although he reported the presence of numerous crustacean, copepod and sponge remains in the faeces of juveniles $(<10 \mathrm{~cm} \mathrm{SL})$. He concluded that smaller fish supplemented their algal diet with animal food, but did not quantify the contribution to their daily nutritional and energy intake (BRUGGEMANN, 1994b). Describing parrotfish resource-use on patch reefs and seagrass beds in Panama, MCAFEE \& MORGaN (1996) noted a small amount of sponge-feeding by parrotfish, particularly $S p$. aurofrenatum.

As further evidence that spicules do not deter fish predation (Chanas \& Pawlik, 1995), the spicules of $G$. gibberosa were abundant in the viscera of fish from Adam's Cut. Geodia gibberosa is very abundant in mangrove environments, where spongivorous fish are absent or rare. When several sponge species, including $G$. gibberosa, were collected in the mangroves and transplanted to the reef, they were 
eaten quickly by the parrotfish $S p$. aurofrenatum and $S p$. chrysopterum (DUNLAP \& Pawlik, 1996; Pawlik, 1997). Like the sponges Tedania ignis and Chondrosia collectrix, G. gibberosa is seldom found on the reefs off Key Largo, and only in locations inaccessible to reef fish, such as underneath coral slabs or in reef crevices (DunlaP \& PAWLIK, 1996). When G. gibberosa is exposed on the reef, it is quickly eaten (DUNLAP \& PAWLIK, 1996; WULFF, 1997). The rarity and small sizes of fish predators in mangrove habitats like Adam's Cut probably explain why sponges persist in exposed locations despite their palatability to fish. Rainbow parrotfish, Sc. guacamaia, probably only feed on sponges in Adam's Cut temporarily, because the juvenile fish migrate to the reefs as they mature (RANDALl, 1968). Adam's Cut, and other mangrove cuts, may provide an important nursery ground for parrotfish, with a high concentration of a preferred food and less competition from other parrotfish than on the reef, in addition to a decreased risk of being eaten by large fish predators that are restricted to reefs.

The gut-oxidation technique used in this study probably gives a conservative estimate of sponge feeding. Some of the demosponges available to parrotfish are aspiculate (e.g., Verongidae) and would leave behind no siliceous spicules. Calcareous sponges have spicules of calcite, and these would dissolve using the acid digestion technique. However, aspiculate sponges are approximately equally distributed between mangrove and reef habitats, and calcareous sponges are very rare. For the purposes of the present study, the acid digestion technique has given good qualitative evidence of sponge consumption by parrotfish.

Parrotfish collected on the reef had much lower amounts of spicules in their viscera than did those collected from Adam's Cut. Any sponge feeding by parrotfish on the reef would be expected to be low, because most sponges on the reef are well defended against predation (PAwLIK etal., 1995). Heavy feeding on the reef was observed only when sponges were transplanted from other habitats (DUNLAP \& PAwLik, 1996) or were more vulnerable due to bleaching (this study). Nevertheless, it is likely that parrotfish, along with the other spongivorous fish such as angelfish and boxfish, consume palatable sponges on the reef as sponges grow out of cryptic locations or are exposed by surge or storms (PAWLIK, 1997, 1998).

The small amounts of spicules isolated from parrotfish viscera, particularly those collected from reef habitats, are likely to reflect both the rapid rate at which these fish pass material through their guts and the paucity of palatable sponges available in reef habitats. With passage times of $<6 \mathrm{~h}$ (BARDach, 1961; SMITH \& Paulson, 1974), the amount of sponge tissue consumed by fish each day may be two to four times the amount indicated by the spicular remains in the viscera. The combined effects of the consumption of even small amounts of sponge tissue by abundant and persistently grazing parrotfish undoubtedly has a dramatic effect on the distribution of the sponge species that they prefer to eat (PAwLIK, 1997, 1998).

\section{Summary}

Over $10 \mathrm{~h}$ of video recordings of fish activity around 40 specimens of the reef sponge Xestospongia muta revealed 45 bites on the surface of normally coloured sponges and 527 bites on four bleached sponges by the parrotfish Sparisoma aurofrenatum, Scarus croicensis and Scarus taeniopterus. Nitric acid digestion of 
the gut tissues of 55 parrotfish collected from mangrove and reef habitats yielded sponge spicule remains, with fish collected from the mangroves containing significantly more spicules in their viscera than those collected from the reef. The spicules of $G$. gibberosa, a sponge that is common in the mangroves but rare in exposed locations on the reef, were abundant in the viscera of parrotfish collected in the mangroves.

\section{Acknowledgements}

Funding for this research was provided by grants from the NOAA-National Undersea Research Program (UNCW9523 to J.R.P), the National Science Foundation (OCE-9158065 and OCE-9314145 to J.R.P.) and the American Museum of Natural History (Lerner Gray Fund for Marine Research grant to M.D.). We thank G. MCFALL and B. WADDELL for assistance with camera tripod construction, J. Styron, O. Rutren and G. MCFall for assistance with parrotfish collection, I. Clavijo and D. LINDQUIST for assistance with parrotfish identification, and R. DILLAMAN and M. GAY for preparing scanning electron micrographs. This is contribution $\# 206$ from the Center for Marine Science Research, UNC-Wilmington.

\section{References}

BakUS, G. J., 1981: Chemical defense mechanisms on the Great Barrier Reef, Australia. Science, 211: 497-499.

BARDACH, J. E., 1961: Transport of calcareous fragments by reef fishes. Science, 133: 98-99.

BELLWOOD, D. R., 1996: Production and reworking of sediment by parrotfishes (family Scaridae) on the Great Barrier Reef, Australia. Mar. Biol., 125: 795-800.

Bohnsack. J. A., D. E. Harper, D. B. MCClellan, D. Sutherland \& M. W. White, 1987: Resource survey of fishes within Looe Key National Marine Sanctuary. NOAA Technical Memoranda Series, US Dept of Commerce, NOAA; $108 \mathrm{pp}$.

Bruggemann, J. H., J. Begeman, E. M. Bosma, P. Verburg \& A. M. Breeman, 1994a: Foraging by the stoplight parrotfish Sparisoma viride. II. Intake and assimilation of food, protein and energy. Mar. Ecol. Prog. Ser., 106: 57-71.

- - M. W. M. KUYPER \& A. M. BREEMAN, 1994b: Comparative analysis of foraging and habitat use by the sympatric Caribbean parrotfish Scarus vetula and Sparisoma viride (Scaridae). Mar. Ecol. Prog. Ser., 112: 51-66.

--, J. R. VAN OPPEN \& A. M. BREEMAN, 1994c: Foraging by the stoplight parrotfish Sparisoma viride. I. Food selection in different, socially determined habitats. Mar. Ecol. Prog. Ser., 106: $41-55$.

Chanas, B. \& J. R. Pawlik, 1995: Defenses of Caribbean sponges against predatory reef fish: II. Spicules, tissue toughness, and nutritional quality. Mar. Ecol. Prog. Ser., 127: 195-211.

ChoAT, J. H., 1982: Fish feeding and the structure of benthic communities in temperate waters. Annu. Rev. Ecol. Syst., 13: 423-449.

,-- 1991: The biology of herbivorous fishes on coral reefs. In: P. F. SALE (Ed.), The Ecology of Fishes on Coral Reefs. Academic Press, San Diego: 120-155.

DunlaP, M. J. \& D. W. Pawlik, 1996: Video-monitored predation by Caribbean reef fishes on an array of mangrove and reef sponges. Mar. Biol., 126: 117-123.

HAY, M. E., 1991: Fish-seaweed interactions on coral reefs, effects of herbivorous fishes and adaptations of their prey. In: P. F. SAlE (Ed.), The Ecology of Fishes on Coral Reefs. Academic Press, San Diego: $96-119$.

HiatT, R. W. \& W. N. Strasburg, 1960: Ecological relationships of the fish fauna on coral reefs of the Marshall Islands. Ecol. Monogr., 30: 65-127.

HIxON, M. A., 1983: Fish grazing and community structure of reef corals and algae: a synthesis of recent studies. NOAA Symposium Ser. Undersea Res., 1: 79-87.

-- \& D. J. BROSTOFF, 1996: Succession and herbivory: effects of differential fish grazing on Hawaiian coral-reef algae. Ecol. Monogr., 66: 67-90.

Hobson, E. S., 1974: Feeding relationships of teleostean fishes on coral reefs in Kona. Hawaii. Fish. Bull., 72: 915-1030. 
HOPPE, W. F., 1988: Growth, regeneration and predation in three species of large coral reef sponges. Mar. Ecol. Prog. Ser., 50: $117-125$.

HoRn, M. H., 1989: Biology of marine herbivorous fishes. Oceanogr. Mar. Biol. Annu. Rev., $27: 167$ 272.

Jones, G. P.. S. G. Ferrell \& P. F. Sale, 1991: Fish predation and its impacts on the invertebrates of coral reefs and adjacent sediments. In: P. F. SALE (Ed.), The Ecology of Fishes on Coral Reefs. Academic Press, San Diego: 156-179.

MCAFEe, S. T. \& B. Morgan, 1996: Resource use by five sympatric parrotfishes in the San Blas Archipelago. Panama. Mar. Biol., 125: 427-437.

Meylan, A., 1988: Spongivory in hawksbill turtles: a diet of glass. Science, 239: 393-395.

PAWLIK, J. R., 1993: Marine invertebrate chemical defenses. Chem. Rev., 93: 1911-1922.

--, 1997: Fish predation on Caribbean reef sponges: an emerging perspective of chemical defenses. In: H. A. Lessios \& I. G. Macintire (Eds.), Proceedings of the 8th International Coral Reef Symposium. Smithsonian Tropical Research Institute, Balboa, Republic of Panama: 1255-1258.

-. 1998: Coral reef sponges: do predatory fishes affect their distribution? Limnol. Oceanogr., 43: 13961399.

--, W. D. Chanas, R. J. Toonen \& W. Fenical, 1995: Defenses of Caribbean sponges against predatory reef fish: I. chemical deterrency. Mar. Ecol. Prog. Ser., 127: 183-194.

RANDALL, J. E., 1967: Food habits of reef fishes of the West Indies. Proceedings of the International Conference on Tropical Oceanography, Studies in Tropical Oceanography. Miami: 665-847.

--, 1968: Caribbean Reef Fishes. TFH Publications, Inc., Ltd, Hong Kong; 318 pp.

--\& I. G. Hartman, 1968: Sponge-feeding fishes of the West Indies. Mar. Biol., 1: 216-225.

Rotzler, K. \& A. C. Macintyre, 1978: Siliceous sponge spicules in coral reef sediments. Mar. Biol.. 49: $147-159$.

Sснміт, E., 1996: Status of reef fishes in the Florida Keys National Marine Sancturary. The Nature Conservancy - Florida and Caribbean Marine Science Center, Florida; 25 pp.

Smith, R. L. \& D. B. Paulson, 1974: Food transit times and gut pH in two Pacific parrotfishes. Copeia, 3: $796-799$.

BLARICOM, G. R. VAN, 1982: Experimental analyses of structural regulation in a marine sand community exposed to oceanic swell. Ecol. Monogr., 52: 283-305.

VICENTE, V.P., 1990; Response of sponges with autotrophic endosymbionts during the coral-bleaching episode in Puerto Rico. Coral Reefs, 3: 199-202.

WulfF, J. L., 1994: Sponge feeding by Caribbean angelfishes, trunkfishes, and filefishes. In: R. W. M. van Soest, T. M. G. van Kempen \& J. C. Braekman (Eds.), Sponges in Time and Space. Balkema, Rotterdam: 265-271.

WULFF, J. L., 1997: Parrotfish predation on cryptic sponges of Caribbean coral reefs. Mar. Biol., 129: 41-52. 